Çukurova Üniversitesi Mühendislik Fakültesi Dergisi, 36(4), ss. 929-940, Aralık 2021

Cukurova University Journal of the Faculty of Engineering, 36(4), pp. 929-940, December 2021

\title{
A Vector-Based Mapping in GIS Environment to Classify Local Climate Zone
}

\author{
Müge ÜNAL ÇÍLEK ${ }^{* 1}$ ORCID 0000-0002-1147-9729 \\ ${ }^{1}$ Firat University, The Faculty of Architecture, Landscape Architecture Department, Adana
}

Geliş tarihi: $02.08 .2021 \quad$ Kabul tarihi: 11.10 .2021

Atıf şekli/ How to cite: ÜNAL ÇILEK, M., (2021). A Vector-Based Mapping in GIS Environment to Classify Local Climate Zone. Çukurova Üniversitesi, Mühendislik Fakültesi Dergisi, 36(4), 929-940.

\begin{abstract}
Local climate zones (LCZ), which are widely used in urban heat island studies, include climate-based classification of the city to determine the climatic differences in the metropolitan area. Therefore, mapping methods have been developed to visualise LCZ classes. Compared to the raster-based mapping method, the vector-based mapping method, which makes a more precise and accurate evaluation, is not widely used due to the difficulty in creating and obtaining a dataset. This study aims to implement a GISbased approach in creating a vector-based LCZ map in the example of Adana City, Turkey. The method of the study consists of five steps: a) determination of classification criteria; b) mapping of each classification criteria via Arc-GIS; c) creation of the decision tree for the creation of the LCZ map; d) overlapping of the classification criteria in line with the decision tree; e) development of suggestions in line with the findings. Vector-based LCZ classification has minimised the classification mistakes that may arise from resolution and has enabled the creation of a highly accurate LCZ map. The LCZ map obtained from the study is expected to be a base map in studies on urban climate studies and to guide decision-makers.
\end{abstract}

Keywords: Vector-based, Local Climate Zone, Geographic Information System (GIS), Multi-Criteria Decision Analysis (MCDA)

\section{Yerel İklim Zonlarının CBS Ortamında Vektör-Tabanlı Haritalanması}

\section{$\ddot{\mathbf{O z}}$}

Kentsel 1sı adası çalışmalarında yaygın olarak kullanılan Yerel İklim Zonları (YİZ) kentsel alanda iklimsel farklılıkların belirlenebilmesi için kentin iklim temelli sınıflanmasını içermektedir. Bu yüzden YİZ sınıflarını görselleştirilmesi için haritalama yöntemleri geliştirilmiştir. Manuel, raster ve vektör tabanlı olmak üzere üç tür haritalama yöntemi bulunmasına rağmen hassas ve doğru değerlendirme yapan vektör tabanlı yöntem yaygın olarak kullanılmamaktadır. Bu yüzden çalışmada vektör tabanlı YİZ haritası üretilmesinde CBS-tabanlı bir yaklaşımın Adana kenti örneğinde gerçekleştirilmesi amaçlanmıştır. Bu doğrultuda çalışmanın yöntemi 5 basamaktan oluşmaktadır. a) sınıflama kriterlerinin belirlenmesi, b) her bir sınıflama kriterinin Arc-GIS aracılığı ile haritalanması, c) YİZ haritasının oluşturulması için karar ağacının oluşturulması, d) karar ağacı doğrultusunda sınıflama kriterlerinin çakıştırılması, e) bulgular doğrultusunda önerilerin geliştirilmesi. YİZ sınıflarının vektör tabanlı sınıflanması, çözünürlükten

\footnotetext{
*Sorumlu yazar (Corresponding author): Muge UNAL CILEK, unalm@cu.edu.tr
} 
kaynaklı olabilecek sınıflama hatalarını en aza indirgemiş ve yüksek doğruluğa sahip YİZ haritasının oluşturulmasını sağlamışıtır. Çalışma sonucunda elde edilen YİZ haritasının kent iklimi ile ilgili çalışmalarda altlık olabilmesi ve karar vericilere yol gösterici olması beklenmektedir.

Anahtar Kelimeler: Vektör-tabanlı, Yerel İklim Zonları, Coğrafi Bilgi Sistemleri (CBS), Çok Kriterli Karar Analizleri (ÇKKA)

\section{INTRODUCTION}

Local Climate Zones (LCZ) define the region with similar surface-air temperature distributions at 100 $\mathrm{m}-10000 \mathrm{~m}$ on the horizontal scale [1]. The main purpose of using this name is that the classes are local/regional in scale, regional in climatic terms. The land use/local climate classification system, defined as the LCZ, uses observational data to differentiate climate zones [2]. The definitions were determined in line with the characteristics of the areas that were similar in geometry and land cover under climatic conditions with calm and clear skies. To determine zones, there are 17 climate zones, divided into two groups as building types (LCZ 1-10) and land cover types (LCZ A$\mathrm{G})$, according to surface characteristics of urban and rural areas (Figure 1). The LCZ classification system is not designed to produce any maps but is intended to classify the areas of constant or mobile heat islands observed in urban or rural areas and to standardise landscape units [3]. However, mapping has been a good approach for visualising the LCZ classes in the urban and rural areas, as the main goal is to present landscape units.

There are three classification methods for mapping local climate zones according to data sources and analytical techniques. These are manual sampling, remote sensing and geographic information systems (GIS). A manual sample has not been widely applied in urban areas, as it is timeconsuming and may lead to different results depending on the person making the classification [4,5]. Classification of satellite images in the creation of LCZ maps by remote sensing is based on object-based image analysis or supervised pixel-based classification techniques [6]. This method provides a fast and cost-effective LCZ classification based on free-access LANDSAT remote sensing images supported by NASA.
On the other hand, the GIS method analyses a more comprehensive data set than remote sensing and manual sampling methods. According to the data structure, there are two types of GIS methods: raster-based and vector-based. The raster method is a suitable method for classifying land surface features and performing spatial analysis. In addition, it has been successfully applied in many studies to produce urban climate maps, urban morphology maps and air circulation maps [7,8]. On the other hand, the vector method is advantageous in terms of defining the shapes of objects with their whole boundaries. In previous LCZ mapping studies, the vector method was generally used to obtain more detailed results $[9,10]$.

In line with these determinations, it is aimed to implement the vector-based classification approach of local climate zones in the example of Adana city. It also aims to create a base map that can be used in urban heat island studies by making a detailed classification of Local Climate Zones. LCZ have common surface characteristics that vary from hundreds to thousands of meters depending on local surface conditions. In the highdensity city of Adana, the surface conditions vary considerably in short distances due to the complex urban morphology. Therefore, this study has emerged to make a detailed and precise classification, the necessity of using the vectorbased GIS-based Multi-Criteria Decision Analysis (MCDA) method for LCZ maps.

\section{MATERIAL AND METHOD}

\subsection{Study Area}

The city of Adana is located in the south of Turkey, in the Eastern Mediterranean part of the Mediterranean Region (Çukurova Region). Adana, 
the 6th most populated city in Turkey $\left(37^{\circ} 00^{\prime}\right.$ north latitude and $35^{\circ} 19^{\prime}$ east longitude), is the center of the Çukurova metropolitan area (Figure 1). The study area consists of the four neighbourhoods with the urban settlement (Seyhan, Çukurova, Yüreğir, Sarıçam) which characterised by high development and settlements region in Adana City.

\begin{tabular}{|c|c|c|c|}
\hline Built types & Definition & Land cover types & Definition \\
\hline I. Compact hi & $\begin{array}{l}\text { Dense mix of tall buildings to tens of } \\
\text { stories. Few or no trees. Land cover } \\
\text { mostly paved. Concrete, steel, stone, } \\
\text { and glass construction materials. }\end{array}$ & A. Dense trees & $\begin{array}{l}\text { Heavily wooded landscape of } \\
\text { deciduous and/or evergreen trees. } \\
\text { Land cover mostly pervious (low } \\
\text { plants). Zone function is natural } \\
\text { forest, tree cultivation, or urban park. }\end{array}$ \\
\hline 2. Con & $\begin{array}{l}\text { Dense mix of midrise buildings ( } 3-9 \\
\text { stories). Few or no trees. Land cover } \\
\text { mostly paved. Stone, brick, tile, and } \\
\text { concrete construction materials. }\end{array}$ & B. Scattered trees & $\begin{array}{l}\text { Lightly wooded landscape of } \\
\text { deciduous and/or evergreen trees. } \\
\text { Land cover mostly pervious (low } \\
\text { plants). Zone function is natural } \\
\text { forest, tree cultivation, or urban park. }\end{array}$ \\
\hline 3. Compact low-rise & $\begin{array}{l}\text { Dense mix of low-rise buildings ( } \mathrm{I}-3 \\
\text { stories). Few or no trees. Land cover } \\
\text { mostly paved. Stone, brick, tile, and } \\
\text { concrete construction materials. }\end{array}$ & C. Bush, scrub & $\begin{array}{l}\text { Open arrangement of bushes, shrubs, } \\
\text { and short, woody trees. Land cover } \\
\text { mostly pervious (bare soil or sand). } \\
\text { Zone function is natural scrubland or } \\
\text { agriculture. }\end{array}$ \\
\hline 4. Ope & $\begin{array}{l}\text { Open arrangement of tall buildings to } \\
\text { tens of stories. Abundance of pervious } \\
\text { land cover (low plants, scattered } \\
\text { trees). Concrete, steel, stone, and } \\
\text { glass construction materials. }\end{array}$ & D. Low plants & $\begin{array}{l}\text { Featureless landscape of grass or } \\
\text { herbaceous plants/crops. Few or } \\
\text { no trees. Zone function is natural } \\
\text { grassland, agriculture, or urban park. }\end{array}$ \\
\hline 5. Open midrise & $\begin{array}{l}\text { Open arrangement of midrise buildings } \\
\text { (3-9 stories). Abundance of pervious } \\
\text { land cover (low plants, scattered } \\
\text { trees). Concrete, steel, stone, and } \\
\text { glass construction materials. }\end{array}$ & E. Bare rock or paved & $\begin{array}{l}\text { Featureless landscape of rock or } \\
\text { paved cover. Few or no trees or } \\
\text { plants. Zone function is natural desert } \\
\text { (rock) or urban transportation. }\end{array}$ \\
\hline 6. Open lc & $\begin{array}{l}\text { Open arrangement of low-rise buildings } \\
\text { ( } 1-3 \text { stories). Abundance of pervious } \\
\text { land cover (low plants, scattered trees). } \\
\text { Wood, brick, stone, tile, and concrete } \\
\text { construction materials. }\end{array}$ & F. Bare soil or sand & $\begin{array}{l}\text { Featureless landscape of soil or sand } \\
\text { cover. Few or no trees or plants. } \\
\text { Zone function is natural desert or } \\
\text { agriculture. }\end{array}$ \\
\hline 7. Lightweight low-ris & $\begin{array}{l}\text { Dense mix of single-story buildings. } \\
\text { Few or no trees. Land cover mostly } \\
\text { hard-packed. Lightweight construction } \\
\text { materials (e.g., wood, thatch, } \\
\text { corrugated metal). }\end{array}$ & G. Water & $\begin{array}{l}\text { Large, open water bodies such as seas } \\
\text { and lakes, or small bodies such as } \\
\text { rivers, reservoirs, and lagoons. }\end{array}$ \\
\hline 8. Large low- & $\begin{array}{l}\text { Open arrangement of large low-rise } \\
\text { buildings ( } 1-3 \text { stories). Few or no } \\
\text { trees. Land cover mostly paved. } \\
\text { Steel, concrete, metal, and stone } \\
\text { construction materials. }\end{array}$ & \multicolumn{2}{|c|}{$\begin{array}{l}\text { Variable or ephemeral land cover properties that change } \\
\text { significantly with synoptic weather patterns, agricultural practices, } \\
\text { and/or seasonal cycles. }\end{array}$} \\
\hline 9. Sparsely built & $\begin{array}{l}\text { Sparse arrangement of small or } \\
\text { medium-sized buildings in a natural } \\
\text { setting. Abundance of pervious land } \\
\text { cover (low plants, scattered trees). }\end{array}$ & s. snow cover & $\begin{array}{l}\text { Leafless deciduous trees (e.g., winter). } \\
\text { Increased sky view factor. Reduced } \\
\text { albedo. } \\
\text { Snow cover }>10 \mathrm{~cm} \text { in depth. Low } \\
\text { admittance. High albedo. }\end{array}$ \\
\hline 10. Heavy industry & $\begin{array}{l}\text { Low-rise and midrise industrial struc- } \\
\text { tures (towers, tanks, stacks). Few or } \\
\text { no trees. Land cover mostly paved } \\
\text { or hard-packed. Metal, steel, and } \\
\text { concrete construction materials. }\end{array}$ & d. dry ground & $\begin{array}{l}\text { Parched soil. Low admittance. Large } \\
\text { Bowen ratio. Increased albedo. } \\
\text { Waterlogged soil. High admittance. } \\
\text { Small Bowen ratio. Reduced albedo. }\end{array}$ \\
\hline
\end{tabular}

Figure 1. The classification of Local Climate Zone [2] 

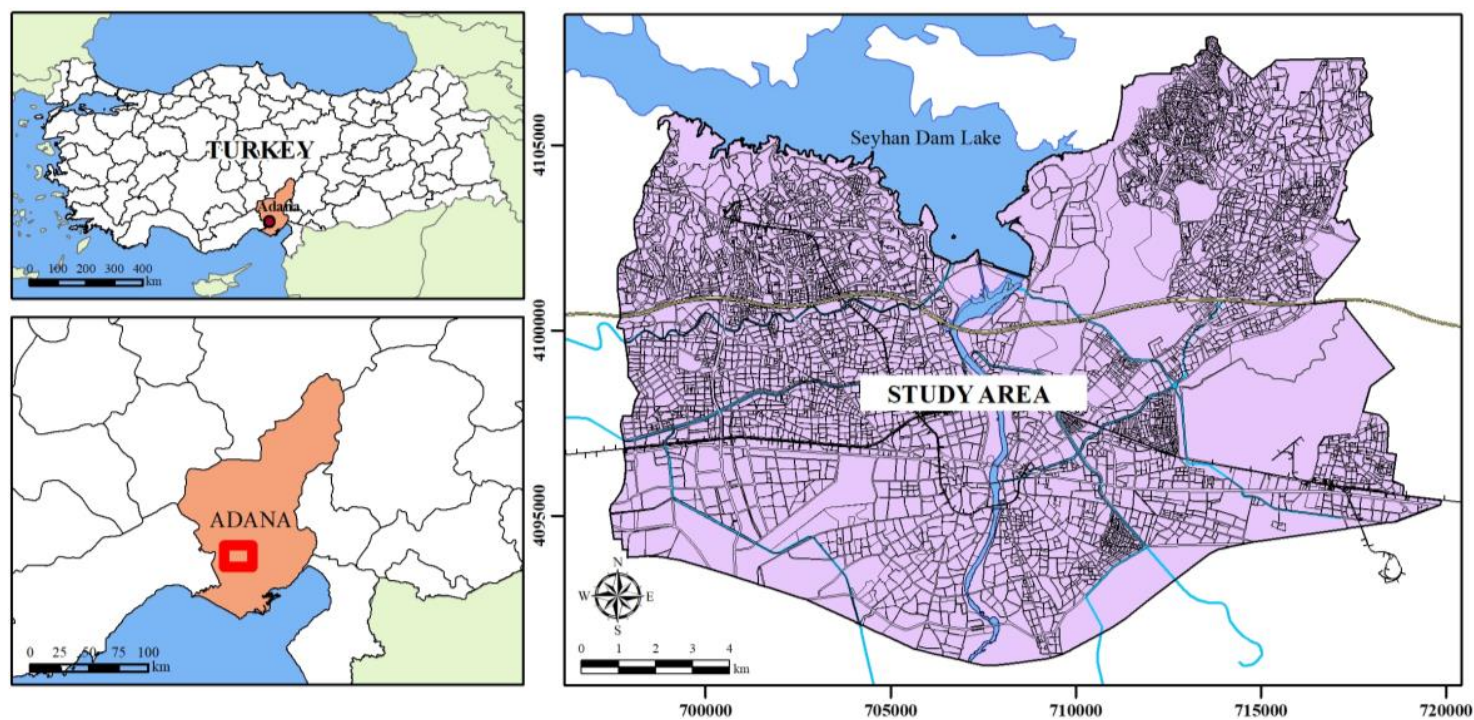

Figure 2. Study area
The city is located in the Mediterranean climate zone with hot summers and mild winters; therefore, annual participation in outdoor activities is longer. The city has a warm and temperate climate, which can be named Csa according to the Köppen-Geiger climate classification.

The average amount of precipitation is $625 \mathrm{~mm}$. Precipitation falls $51 \%$ in winter, $26 \%$ in spring, $18 \%$ in autumn, and $5 \%$ in summer. The coldest month is January at an average of $9{ }^{\circ} \mathrm{C}$, and the warmest month is August at an average of $28{ }^{\circ} \mathrm{C}$. The hottest annual period, that is, the period when the temperature does not fall below $21^{\circ} \mathrm{C}$, is quite long. Again in this period, the average daily relative humidity is above $65 \%$ [11].

The high agricultural potential of Adana City has led to the city's rapid development since the 1930s. City has been planned in the 1940s, but it resulted in the revision of the plans to meet the housing need of the increasing population [12]. Consequently, the city was formed as it is today. The Adana City developed around the city's historical core with high density and low rise building characteristics in the southern part of the study area. However, today, the city consists of open high-rise buildings in the northern part of the study area.

\subsection{Data}

To determine LCZ classes of Adana City, data were obtained from different institutions and organisations. There are as follows:

- Adana City Environmental Plan (1:100.000),

- Adana Master Development Plan (1:25.000 and $1: 50.000)$

- Adana Implementation Development Plan $(1: 1.000)$

- and Adana base map including urban development areas data.

- Moreover, aerial photographs, Urban Atlas data, and previous studies and reports are also supplementary materials.

The software used in the study are:

- GIS-based Arc-GIS software used for performing spatial analyses, including the classification of criteria and creating maps 


\subsection{Method}

The method of the study consists of five stages;

- Determination of classification criteria,

- Mapping of classification criteria,

- Developing the decision tree to determine LCZ classes,

- Overlapping the classification criteria,

- Developing suggestions according to the findings a) Determination of classification criteria: In the LCZ approach, which is dependent on the urban morphology, many criteria were used in the evaluation, but the main elements in the determination of LCZ classes were the characteristics of the settlement areas. These are building height $(\mathrm{BH})$, aspect ratio (building height/street width- $\mathrm{H} / \mathrm{W}$ ), a pervious surface fraction (PSF), and impervious surface fraction (ISF). Each classification criteria has different threshold values (Table 1), which creates separate layers in determining LCZ classes.

Table 1. Values of geometric and surface cover properties of each LCZs type [2]

\begin{tabular}{|c|c|c|c|c|c|c|c|}
\hline & $\begin{array}{l}\text { Local Climate } \\
\text { Zone (LCZ) }\end{array}$ & $\begin{array}{l}\text { Sky view } \\
\text { factor }^{\mathrm{a}} \\
(\mathrm{SVF})\end{array}$ & Aspect ratio $^{\text {b }}$ & $\begin{array}{l}\text { Building } \\
\text { surface } \\
\text { fraction }^{\mathrm{c}} \\
\text { (BSF) }\end{array}$ & $\begin{array}{l}\text { Impervilous } \\
\text { surface } \\
\text { fraction }^{d} \\
\text { (ISF) }\end{array}$ & $\begin{array}{l}\text { Pervious } \\
\text { surface } \\
\text { fraction }^{\mathrm{e}} \\
\text { (PSF) }\end{array}$ & $\begin{array}{l}\text { Height of } \\
\text { roughness } \\
\text { elements } \\
\text { (m) }\end{array}$ \\
\hline \multirow{10}{*}{ 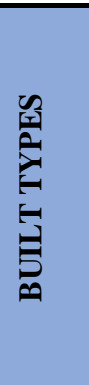 } & LCZ-1 & $0.2-0.4$ & $>2$ & $40-60$ & $40-60$ & $<10$ & $>25$ \\
\hline & LCZ -2 & $0.3-0.6$ & $0.75-2$ & $40-70$ & $30-50$ & $<20$ & $10-25$ \\
\hline & LCZ -3 & $0.2-0.6$ & $0.75-1.5$ & $40-70$ & $20-50$ & $<30$ & $3-10$ \\
\hline & LCZ -4 & $0.5-0.7$ & $0.75-1.25$ & $20-40$ & $30-40$ & $30-40$ & $>25$ \\
\hline & LCZ -5 & $0.5-0.8$ & $0.3-0.75$ & $20-40$ & $30-50$ & $20-40$ & $10-25$ \\
\hline & LCZ -6 & $0.6-0.9$ & $0.3-0.75$ & $20-40$ & $20-50$ & $30-60$ & $3-10$ \\
\hline & LCZ -7 & $0.2-0.5$ & $1-2$ & $60-90$ & $<20$ & $<30$ & $2-4$ \\
\hline & LCZ -8 & $>0.7$ & $0.1-0.3$ & $30-50$ & $40-50$ & $<20$ & $3-10$ \\
\hline & LCZ -9 & $>0.8$ & $0.1-0.25$ & $10-20$ & $<20$ & $60-80$ & $3-10$ \\
\hline & LCZ -10 & $0.6-0.9$ & $0.2-0.5$ & $20-30$ & $20-40$ & $40-50$ & $5-15$ \\
\hline \multirow{7}{*}{ 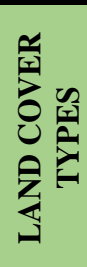 } & $\mathbf{L C Z}-\mathbf{A}$ & $<0.4$ & $>1$ & $<10$ & $<10$ & $>90$ & $3-30$ \\
\hline & LCZ -B & $0.5-0.8$ & $0.25-0.75$ & $<10$ & $<10$ & $>90$ & $3-15$ \\
\hline & $\mathrm{LCZ}-\mathrm{C}$ & $0.7-0.9$ & $0.25-1.0$ & $<10$ & $<10$ & $>90$ & $<2$ \\
\hline & LCZ -D & $>0.9$ & $<0.1$ & $<10$ & $<10$ & $>90$ & $<1$ \\
\hline & LCZ -E & $>0.9$ & $<0.1$ & $<10$ & $>90$ & $<10$ & $<0.25$ \\
\hline & LCZ -F & $>0.9$ & $<0.1$ & $<10$ & $<10$ & $>90$ & $<0.25$ \\
\hline & LCZ -G & $>0.9$ & $<0.1$ & $<10$ & $<10$ & $>90$ & - \\
\hline \multicolumn{8}{|c|}{ a Ratio of the amount of sky hemisphere visible from ground level to that of an unobstructed hemisphere } \\
\hline \multicolumn{8}{|c|}{$\begin{array}{l}\text { b Mean height-to-width ratio of street canyons (LCZs 1-7), building spacing (LCZs 8-10), and tree spacing } \\
\text { (LCZs A-G) }\end{array}$} \\
\hline \multicolumn{8}{|c|}{ c Ratio of building plan area to total plan area $(\%)$} \\
\hline \multicolumn{8}{|c|}{$\mathrm{d}$ Ratio of impervious plan area (paved, rock) to total plan area (\% } \\
\hline \multicolumn{8}{|c|}{ e Ratio of pervious plan area (bare soil, vegetation, water) to total plan area (\%) } \\
\hline \multicolumn{8}{|c|}{ f Geometric average of building heights (LCZs 1-10) and tree/plant heights (LCZs A-F) (m) } \\
\hline
\end{tabular}

b) Mapping the classification criteria: Mathematical formulas were used to create maps for each criterion in the GIS environment (Table 2). To determine the class differences within the layers in detail, the parcel boundaries in the study area were taken into account. Maps for each criterion were created by applying the determined formulas for each parcel in the GIS environment. Thus, more sensitive and accurate LCZ classifications were obtained. 
Table 2. The definition of physical parameters and calculation methods used to classify local climate zones (LCZs) [12]

\begin{tabular}{|c|c|c|}
\hline $\begin{array}{l}\text { PHYSICAL } \\
\text { PARAMETERS }\end{array}$ & DEFINITIONS & EQUATION \\
\hline $\begin{array}{l}\text { BH-Building } \\
\text { height }(\mathrm{m})\end{array}$ & $\begin{array}{l}\text { One of the main parameters used for LZC classification is the } \\
\text { average building heights to determine high-rise, midrise, and low- } \\
\text { rise LCZ classes [5]. Therefore the mean building height was found } \\
\text { by multiplying the number of floors and the average floor height ( } 3 \\
\mathrm{~m} \text { ) and dividing it by the total number of buildings in a parcel. }\end{array}$ & $\begin{array}{l}\qquad B H=\frac{\sum(B f \times B f h)}{n} \\
\text { BH: Building height } \\
\text { Bf: The number of stories } \\
\text { Bfh: Story elevation (3m) } \\
\text { n: The total number of building in a } \\
\text { parcel }\end{array}$ \\
\hline $\begin{array}{l}\text { BSF-Building } \\
\text { surface fraction } \\
(\%)\end{array}$ & $\begin{array}{l}\text { BSF is the fraction of land surface covered with buildings }[5,13,14] \text {. } \\
\text { It is a crucial parameter employed to classify the built type (BSF }> \\
0.10 \text { ) and land cover type (BSF }<0.10 \text { ) in addition to categorizing } \\
\text { compact (BSF }>0.40 \text { ) and open }(0.10<\text { BSF }<0.40) \text { LCZ classes in } \\
\text { an urban area. It is calculated by the ratio of the total building } \\
\text { footprint to the total parcel area, and the BSF of each polygon was } \\
\text { calculated for each parcel. }\end{array}$ & $\begin{array}{l}\qquad \mathrm{BSF}=\frac{\sum_{\mathrm{i}=1}^{\mathrm{n}} \mathrm{Bfa}}{\mathrm{Pa}} \times 100 \\
\text { BSF: Building surface fraction } \\
\text { Bfa: Building footprint area } \\
\mathrm{n} \text { : The total number of building in a } \\
\text { parcel } \\
\text { Pa: Total parcel area }\end{array}$ \\
\hline $\begin{array}{l}\mathrm{H} / \mathrm{W} \text {-Aspect } \\
\text { ratio }\end{array}$ & $\begin{array}{l}\text { The aspect ratio is one of the most challenging calculated } \\
\text { parameters because the building height and street width vary in the } \\
\text { same street }[5,15] \text {. Therefore, the aspect ratio was calculated for } \\
\text { each parcel. It is generally divided into two values: H/W }<0.75 \text { and } \\
\mathrm{H} / \mathrm{W}>0.75 \text {. The mean aspect ratio was found using the mean } \\
\text { building height divided by the mean street width. The total street } \\
\text { width computed the average street width around the parcel divided } \\
\text { by the edge number of parcels. }\end{array}$ & $\begin{array}{l}\qquad \mathrm{H} / \mathrm{W}=\frac{\mathrm{BH}}{\mathrm{SW}} \\
\text { H: Height } \\
\text { W: Width } \\
\text { BH: Building height } \\
\text { SG: Street width }\end{array}$ \\
\hline $\begin{array}{l}\text { PSF-Pervious } \\
\text { surface fraction } \\
(\%)\end{array}$ & $\begin{array}{l}\text { Waterbody and vegetated areas, which mitigates the urban heat } \\
\text { island effect by evaporation, described as a pervious surface in a } \\
\text { metropolitan area. The pervious surface fraction (PSF) is an } \\
\text { important parameter used to define LCZ classes at a local scale. PSF } \\
\text { is the percentage of pervious surfaces in a parcel area for this study. } \\
\text { The percentage of water bodies was determined using the planning } \\
\text { data, while remote sensing data decided the presence of vegetation } \\
\text { cover. To determine PSF, the Landsat data of the study area were } \\
\text { used to derive a Normalised Difference Vegetation Index (NDVI) } \\
\text { image calculated by the following equation. } \\
\qquad \text { NDVI= NIR-Red } \\
\text { According to the publication of NASA, NDVI values were assumed } \\
\text { to be vegetation }>0.2 \text {, water= } 0.0 \text {, and } 0<\text { impervious surface }<0.2 \\
\text { [5,13,16,17]. Therefore, the raster-based NDVI map was developed } \\
\text { to identify PSF and was converted into a vector-based plan. } \\
\text { Therefore, PSF was determined for each parcel in the study area. }\end{array}$ & $\begin{array}{l}\qquad \mathrm{PSF}=\frac{\sum_{\mathrm{i}=1}^{\mathrm{n}} \mathrm{PSAi}}{\mathrm{Pa}} \times 100 \\
\text { PSF: Pervious surface fraction } \\
\text { PSA: The area of pervious surface } \\
\text { Pa: Total parcel area }\end{array}$ \\
\hline $\begin{array}{l}\text { ISF-Impervious } \\
\text { surface fraction } \\
(\%)\end{array}$ & $\begin{array}{l}\text { The impervious surface fraction (ISF) in a parcel is defined as the } \\
\text { fraction of paved surface outside buildings }[5,13,17,18] \text {. ISF cannot } \\
\text { be calculated in a high-density city because its calculation requires } \\
\text { BSF and PSF values. }\end{array}$ & $\begin{array}{l}\quad \text { ISF }=(1-(B S F+P S F)) \times 100 \\
\text { ISF: Impervious surface fraction } \\
\text { PSF: Pervious surface fraction } \\
\text { BSF: Building surface fraction }\end{array}$ \\
\hline Land use map & $\begin{array}{l}\text { To classify the land use types of LCZ, the characteristic of land use } \\
\text { and land cover types for each parcel and polygons were identified. }\end{array}$ & \\
\hline
\end{tabular}


c) Developing a decision tree: In the study, a decision tree was developed by considering the threshold values determined for each criterion by [2]. Although different values were determined for each class, some classes have similar values in terms of some properties. To decide the suitable LCZ classes, the differences of other characteristics take into account. Firstly, the building types and land cover types were distinguished by considering the BSF. Areas with a building surface fraction value greater than $10 \%$ represented building areas, while areas less than $10 \%$ represented land cover types. This distinction constitutes the basic distinction of building types and land cover types before the detailed classification of LCZ classes. The threshold values were decisive in determining building types (LCZ 1-10); on the other hand, urban atlas data was used to classify the land cover classes (LCZ A-G).
Secondly, building types were distinguished according to building height by considering the number of stories. Building heights are defined as "high-rise" over 9 stories, "mid-rise" 3-9 stories, and "low-rise" buildings lower than 3 stories. Thirdly, the density of building were determined with BSF. Areas with more than $40 \%$ structure within an area are defined as "compact", while areas below $40 \%$ are defined as "open". According to the second and third steps of a decision tree, compact high-rise LCZ 1, compact midrise LCZ 2, open high-rise LCZ 4, and open midrise LCZ 5 were determined. However, building height and BSF are not sufficient to determine other LCZ classes with low-rise buildings. Therefore, these LCZ classes were determined, taking into consideration of other characteristics differences. On the other hand, Urban Atlas data were used in the classification of land cover types.

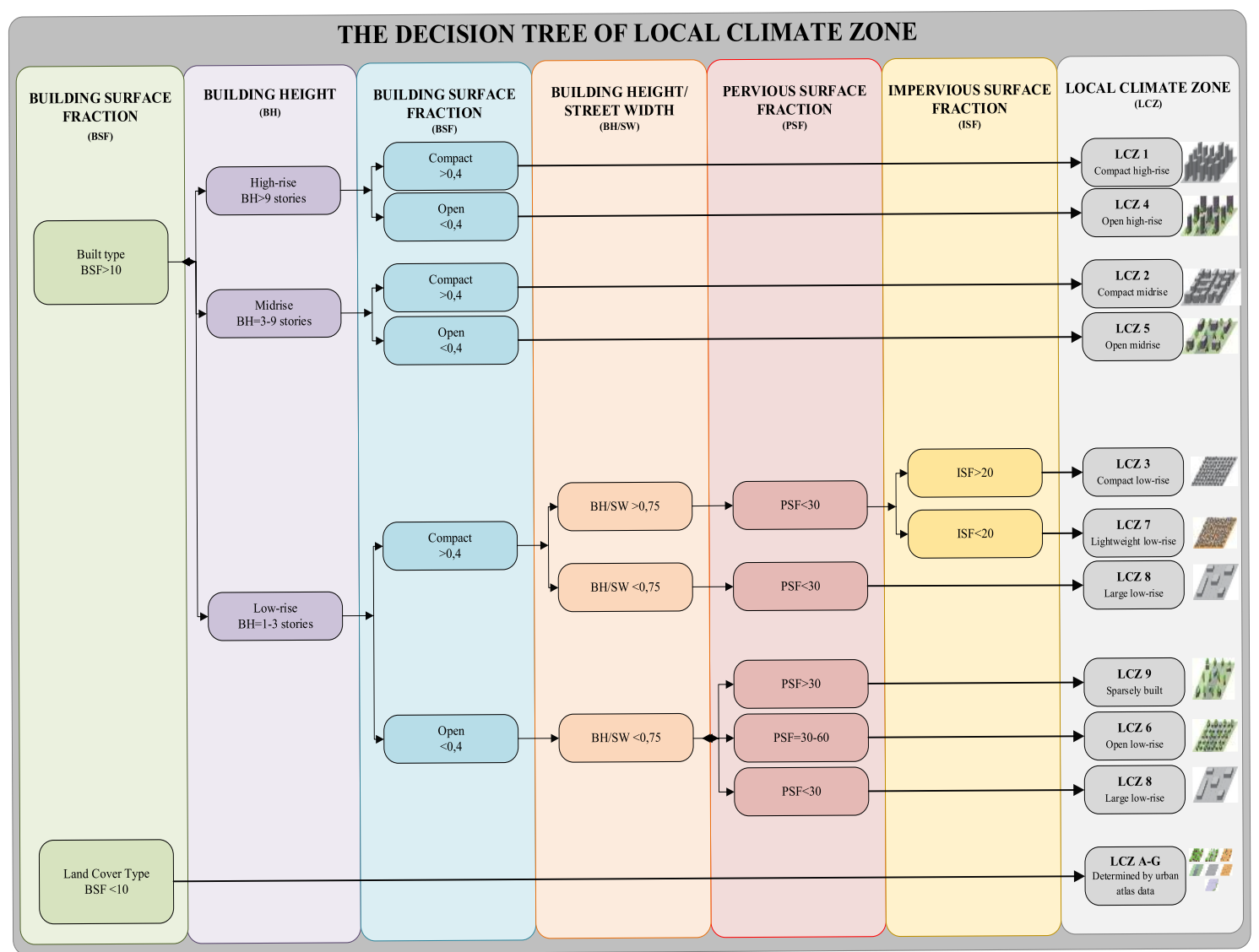

Figure 3. The decision tree of LCZ mapped in the GIS environment [12] 
d) Overlapping of layers: LCZ classes were obtained by overlapping the classification criteria through Arc-GIS in line with the first three steps of the methodology.

\section{RESULTS}

To classify LCZ, firstly, the analysis was performed for each building parcel in Adana City. GIS-based vector method was preferred for easy, precise, detailed, and comprehensive analysis of LCZ classes. Secondly, the values and calculations. Secondly, the values and formulas determined in the method of the study were taken into account for the LCZ classifications. The building height, aspect ratio, building surface fraction, impermeable surface ratio, permeable surface ratio, existing vegetation, and land cover characteristics were defined for each building parcel and maps were produced for each classification criteria (Figure 4). Figure 4 shows the following issue:

- Building height (BH): Areas without buildings, such as roads, airports, agricultural areas, green spaces etc., have a total percentage of $37.2 \%$ in the study area. Low rise buildings (1-3-storey), which form the predominant building type of the city, have a large proportion with $49.7 \%$ of the study area. Highrise buildings (>9-storey) constitute $8.3 \%$ of the north of the study area. Mid-rise facilities (3-9-storey) located in the city center and the city's western parts include only $4.3 \%$ of the area.

- Building surface fraction (BSF): BSF, firstly, was used to distinguish the building types and land cover types of LCZ in the study area. Secondly, it was used to determine building density divided into two groups, including compact and open. Figure 4 shows that building density in the city center $(10.0 \%)$ is generally compact, while the other building areas constitute $36.8 \%$ of the study area.
- Aspect ratio (H/W): $\mathrm{BSF}$, aspect ratio and $\mathrm{BH}$ affect the LCZ classification because of caused different aspect ratios. Since there may be different building heights on the same street, each building parcel needs to be separately calculated. In building types of LCZ, as the canyon effect increases in the higher aspect ratio, the canyon effect decreases in the lower aspect ratio. Therefore, the canyon effects are high in the high-rise building parcels in the northern part of the study area. While the canyon effect is decreased in low-rise building parcels. The dominant aspect ratios in the other parts of the study area are $0.30-0.50$ and 0.50 0.75 , with a total of $36.2 \%$.

- ISF and PSF: Although permeable and impermeable surface fractions are similar to each other in terms of classification values, these values are not shown in contrast areas. The permeable surface fraction (PSF) is determined by the percentage of permeable surfaces (bare soil, vegetation, etc.) in the total size of the building parcel. While the impervious surface fraction (GSF) is determined by the percentage of impervious surfaces (asphalt, stone, concrete) except building surface area in the total building parcel area. The study is covered by building area have a total percentage of $62.8 \%$. Areas without buildings such as roads, airports, agricultural areas, green spaces etc., have a total percentage of $37.2 \%$ in the study area. However, all of these areas have not high permeable surface fractions. Agricultural areas have generally located the surrounding urban settlements. As you move away from the city center, the pervious surface fraction ratio increases. In buildings area, green spaces generally have higher pervious surface areas. On the other hand, the compact building area, which is located in the southern part of the study area, has a higher impervious surface fraction. 

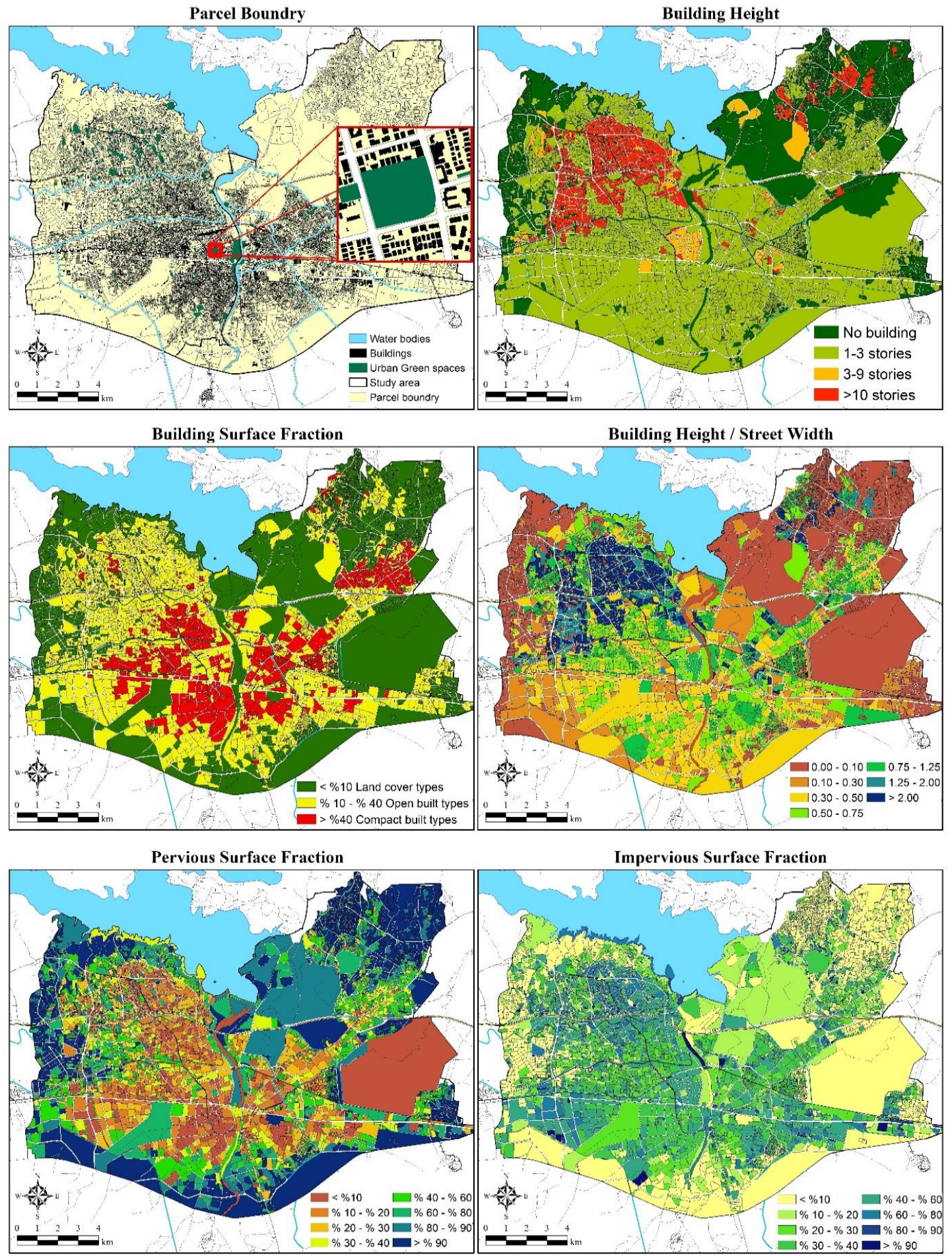

Figure 4. GIS-based map for LCZ indicators [12] 
As a result of overlaying the classification criteria maps in the direction of the decision tree, the LCZ map of Adana City was obtained (Figure 5). The distribution of each LCZ class in the study area is given in Table 3 . While $46.8 \%$ of the study area is composed of LCZ 1-10 building types, $53.2 \%$ is LCZ A-G, which are land cover types. Although all LCZ classes (except LCZ F) exist in the study area, some classes are dominant. The city center, where low-rise buildings are located, is generally defined as LCZ 3 due to its compact building pattern.
From the city center to the south, the building pattern changes as the open low-rise LCZ 6 class. In the north-northwest parts of the city, where open high-rise buildings are located, the LCZ 4 class is dominant. In the areas between LCZ 4 and the Seyhan Dam Lake, the areas with natural vegetation are LCZ C. LCZ A, where areas with dense vegetation are generally located around the lake and river. In the northwestern part of the city, it is defined as LCZ D, as there are usually agricultural areas.

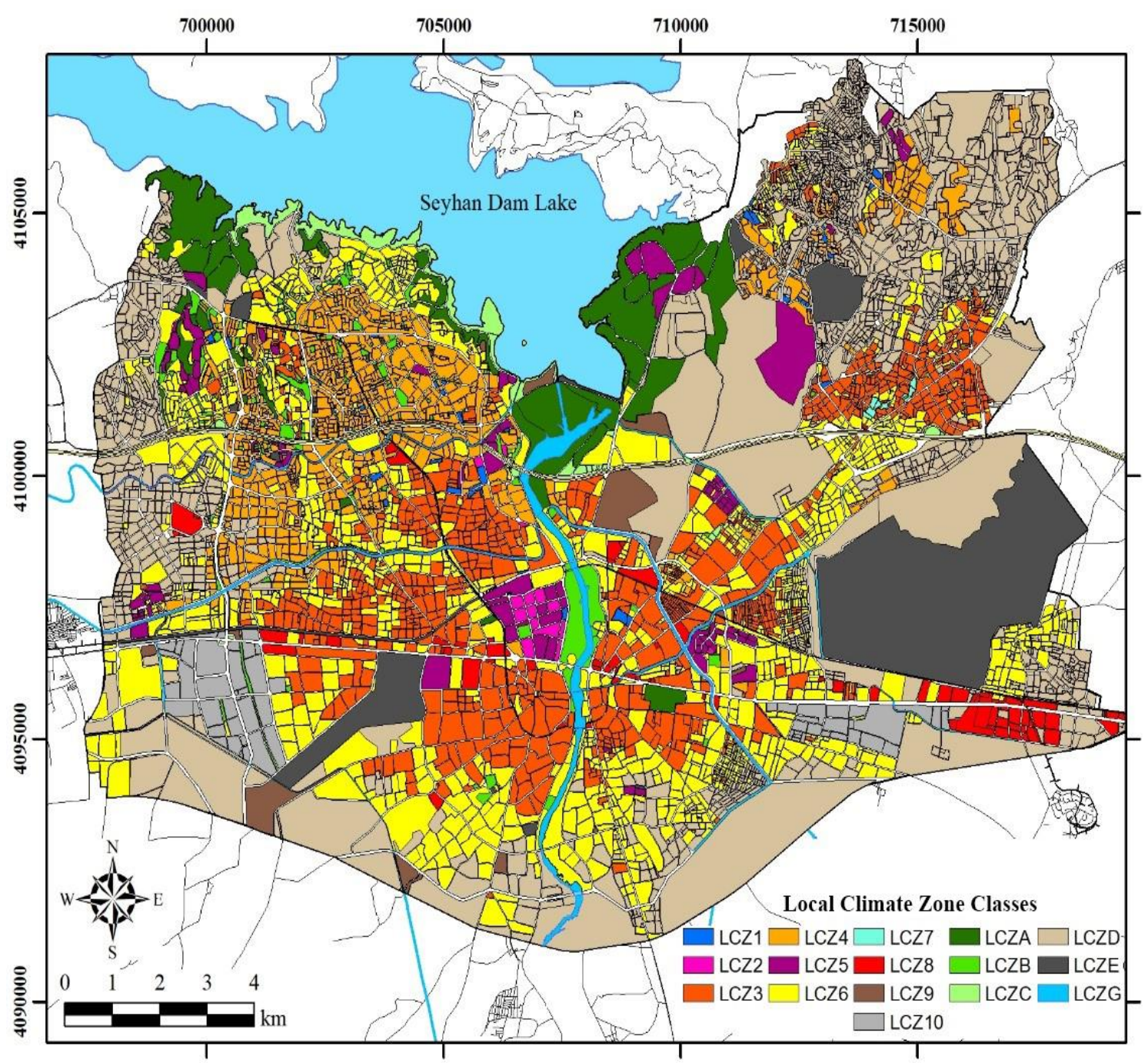

Figure 5. Adana city local climate zone map 
Table 1. The distribution of Local Climate Zone classes

\begin{tabular}{|c|c|c|c|c|c|}
\hline \multicolumn{3}{|c|}{ BUILDING TYPES } & \multicolumn{3}{|c|}{ LAND COVER TYPES } \\
\hline $\begin{array}{c}\text { LCZ } \\
\text { Classes }\end{array}$ & $\begin{array}{c}\text { Area Size } \\
\text { (Ha) }\end{array}$ & $\begin{array}{c}\text { Percentage } \\
(\%)\end{array}$ & $\begin{array}{c}\text { LCZ } \\
\text { Classes }\end{array}$ & $\begin{array}{c}\text { Area Size } \\
\text { (Ha) }\end{array}$ & $\begin{array}{c}\text { Percentage } \\
(\%)\end{array}$ \\
\hline 1 & 59,72 & 0,2 & $\mathbf{A}$ & $2.051,36$ & 7,0 \\
\hline 2 & 69,16 & 0,2 & B & 684,51 & 2,3 \\
\hline 3 & $2.654,29$ & 9,1 & $\mathbf{C}$ & 185,08 & 0,6 \\
\hline 4 & $2.261,40$ & 7,8 & D & $8.372,45$ & 28,7 \\
\hline 5 & $1.298,61$ & 4,5 & $\mathbf{E}$ & $4.025,70$ & 13,8 \\
\hline 6 & $5.686,18$ & 19,5 & $\mathbf{F}$ & - & - \\
\hline 7 & 15,36 & 0,1 & $\mathbf{G}$ & 214,18 & 0,7 \\
\hline 8 & 358,92 & 1,2 & & & \\
\hline 9 & 655,50 & 2,2 & & & \\
\hline 10 & 584,58 & 2,0 & & & \\
\hline & & & Study a & $29.176,06$ & 100 \\
\hline
\end{tabular}

\section{CONCLUSION}

Local Climate Zone studies are widely used in urban heat island studies because they classify according to the surface properties of cities. LCZ, based on urban morphology, many studies have used a raster-based method that depends on remote sensing data and requires supervised classification and verification [13,19-21]. However, in this study, GIS-based analyses were performed to perform vector-based classification. The advantages of vector-based LCZ classification can be listed as follows:

- While raster-based methods require local knowledge, the vector-based method is advantageous in analysing and overlapping LCZ criteria in the GIS environment.

- While there are manual correction possibilities for classes that may be faulty in vector-based analysis, it is challenging to correct faulty classes in raster-based analysis.

- Raster-based analyses have course resolution, resulting in data loss and inclusion of different classes of LCZ classes. On the other hand, since the numerical data of the city are used with coordinates in vector-based analyses, the errors that may arise from the resolution are minimised.

Because of these advantages, vector-based analyses can be preferred for more precise urban heat island studies or change analysis evaluations. In addition, a large dataset and base data will be obtained that can be a base map for urban climate studies and guide decision-makers.

\section{REFERENCES}

1. Stewart, I., Oke, T., 2009. Classifying Urban Climate Field Sites by "Local Climate Zones": the Case of Nagano, Japan. In: The Seventh International Conference on Urban Climate. The Seventh International Conference on Urban Climate, 29 June-3 July 2009, Yokohama, Japan, 1-5.

2. Stewart, I.D., Oke, T.R., 2012. Local Climate Zones for Urban Temperature Studies. Bulletin of the American Meteorological Society, 93(12), 1879-1900.

3. Kántor, N., Unger, J., 2011. The Most Problematic Variable in the Course of Humanbiometeorological Comfort Assessment-The Mean Radiant Temperature. Central European Journal of Geosciences, 3(1), 90-100.

4. Chen, Y., Zheng, B., Hu, Y., 2020. Mapping Local Climate Zones Using ArcGIS-Based Method and Exploring Land Surface Temperature Characteristics in Chenzhou, China. Sustainability, 12(7), 2974.

5. Zheng, Y., Ren, C., Xu, Y., Wang, R., Ho, J., Lau, K., Ng, E., 2018. GIS-based Mapping of Local Climate Zone in the High-density City of Hong Kong. Urban Climate, 24, 419-448. 
6. Bechtel, B., Daneke, C., 2012. Classification of Local Climate Zones Based on Multiple Earth Observation Data. IEEE Journal of Selected Topics in Applied Earth Observations and Remote Sensing, 5.4: 1191-1202.

7. Ng, E., Yuan, C., Chen, L., Ren, C., Fung, J.C.H., 2011. Improving the Wind Environment in High-density Cities by Understanding Urban Morphology and Surface Roughness: A Study in Hong Kong. Landscape and Urban Planning, 101(1), 59-74.

8. Ren, C., Lau, K.L., Yiu, K.P., Ng, E., 2013. The Application of Urban Climatic Mapping to the Urban Planning of High-density Cities: The Case of Kaohsiung, Taiwan. Cities, 31, 1-16.

9. Perera, N., 2015. Climate-sensitive Urban Public Space: a Sustainable Approach to Urban Heat Island Mitigation in Colombo, Sri Lanka. University of Moratuwa, Department of Architecture, PhD Thesis, Sri Lanka, 273.

10. Gál, T., Bechtel, B., Unger, J., 2015. Comparison of Two Different Local Climate Zone Mapping Methods. ICUC9-9 ${ }^{\text {th }}$ International Conference on Urban Climates, Toulouse, France (20-24 July).

11. TSMS, 2019. Turkish State Meteorological Service [online]. Available from: https://mgm.gov.tr/eng/forecast-cities.aspx.

12. Unal Cilek, M., Cilek, A., 2021. Analyses of Land Surface Temperature (LST) Variability Among Local Climate Zones (LCZs) Comparing Landsat-8 and ENVI-met Model Data. Sustainable Cities and Society, 69, 102877.

13. Estacio, I., Babaan, J., Pecson, N.J., Blanco, A.C., Escoto, J.E., Alcantara, C.K., 2019. GISbased Mapping of Local Climate Zones Using Fuzzy Logic and Cellular Automata. International Archives of the Photogrammetry, Remote Sensing and Spatial Information Sciences-ISPRS Archives, 42 (4/W19), 199-206.

14.Zhou, X., Okaze, T., Ren, C., Cai, M., Ishida, Y., Watanabe, H., Mochida, A., 2020. Evaluation of Urban Heat Islands Using Local Climate Zones and the Influence of Sea-land Breeze. Sustainable Cities and Society, 55 (April 2019), 102060

15. Ng, E., Cheng, V., 2012. Urban Human
Thermal Comfort in Hot and Humid Hong Kong. Energy and Buildings, 55, 51-65.

16. Bartesaghi Koc, C., Osmond, P., Peters, A., Irger, M., 2018. Understanding Land Surface Temperature Differences of Local Climate Zones Based on Airborne Remote Sensing Data. IEEE Journal of Selected Topics in Applied Earth Observations and Remote Sensing, 11(8), 2724-2730.

17. Quan, J.L., 2019. Enhanced Geographic Information System-based Mapping of Local Climate Zones in Beijing, China. Science China Technological Sciences, 62(12), 2243-2260.

18. Stewart, I.D., 2013. Local Climates of the City. Architectural Design, 83(4), 100-105.

19. Gholami, R., Beck, C., 2019. Towards the Determination of Driving Factors of Varying LST-LCZ Relationships: A Case Study Over 25 Cities. Geographica Pannonica, 23(4), 289-307.

20. Bande, L., Manandhar, P., Marpu, P., Battah, M., Al, 2020. Local Climate Zones Definition in Relation to ENVI-met in the City of Dubai, UAE. IOP Conference Series: Materials Science and Engineering, 829(1), 012013.

21. Ochola, E.M., Fakharizadehshirazi, E., Adimo, A.O., Mukundi, J.B., Wesonga, J.M., Sodoudi, S., 2020. Inter-local Climate Zone Differentiation of Land Surface Temperatures for Management of Urban Heat in Nairobi City, Kenya. Urban Climate, 31 (November), 100540. 